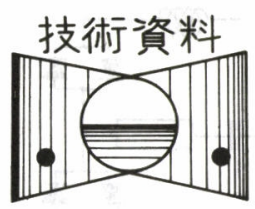

\title{
燃料油処理用ハイパワ超音波励振源 の一方式についで
}

\section{畑 中 義 博**}

\author{
One of the Methods of High Power Ultrasonic Exciting Source \\ for Fuel Oil Treatment
}

By Yoshihiro Hatanaka

\begin{abstract}
Recently, some kinds of high-frequency inverters using reverse-conducting thyristors have been attractively used as the exciting sources for ultrasonic transducer systems.

Both of voltage and current-fed inverters have been widely used for these purpose. In general, there are some problems in starting and high $\mathrm{d} i / \mathrm{d} t$ for the current-fed type inverters, and also in high $\mathrm{d} v / \mathrm{d} t$ for the voltage-fed type inverters. Furthermore the maximum frequency of these inverters are limited by turn-off time rating.

This paper describes some transient and steady-state characteristics of a center-tapped highfrequency inverter using ASCR, which is capable of operating at $100 \mathrm{KHz}$. First of all, the basic operation of the inverter is discussed and then the normalized numerical solution is elucidated. Effects of inductance ratio and capacitance ratio on the steady-state characteristics for the inverter are fully discussed on the basis of numerical analysis.

Secondly, load characteristics attributed to load variations on the steady-state operation are illustrated in relation to some normalized circuit constants and operating frequency.

In addition, the transient response of margin time of commutation for ASCR is studied in relation to the practical maximum operating frequency.
\end{abstract}

\section{1. まえがき}

近年, 低質重油対策の一方式として, 超音波を利用し た燃料油の改質 ${ }^{1,2)}$, あるいは超音波ホモジナイザによ る燃費改善 ${ }^{8,4)}$ が報告されている. 超音波ホモジナイザ による燃費改善は, W/O (water in oil : 油中水滴型) エマルジョン燃料適用による低燃費, 低 $\mathrm{NO}_{\mathrm{x}}$ 化の実現で あるが, 超音波以外によるエマルジョン燃料の生成, 適 用の実績む報告 ${ }^{5 \sim 8)}$ されている. エマルジョン燃料の適 用においては，W/Oエマルジョンの水分\%のみではな く, 油中水滴の微粒度が安定性及び燃焼に大きく影響す $3^{6)}$. 油中水滴の最適粒径に関しては, 今後種々の燃焼 条件の下に検討を重ねる必要があるが，2 5 ミクロン が最適という報告 ${ }^{9,10)}$ あある. 5 ミクロン程度までの油 中水滴の微粒化は, 種々の機械的方法 ${ }^{5 \sim 7,11)}$ であ可能で あるが, 2 ミクロン程度に均一に分散したW/O エマル ジョンの実現には, 超音波ホモジナイザ(図 1)が適して

\footnotetext{
* 原稿受付 昭和 59 年 11 月 15 日

昭和 59 年秋季学術講演 (昭和 59 年 10 月 24 日)

** 正会員 海技大学校(壳屋市西蔵町 12-24)
}
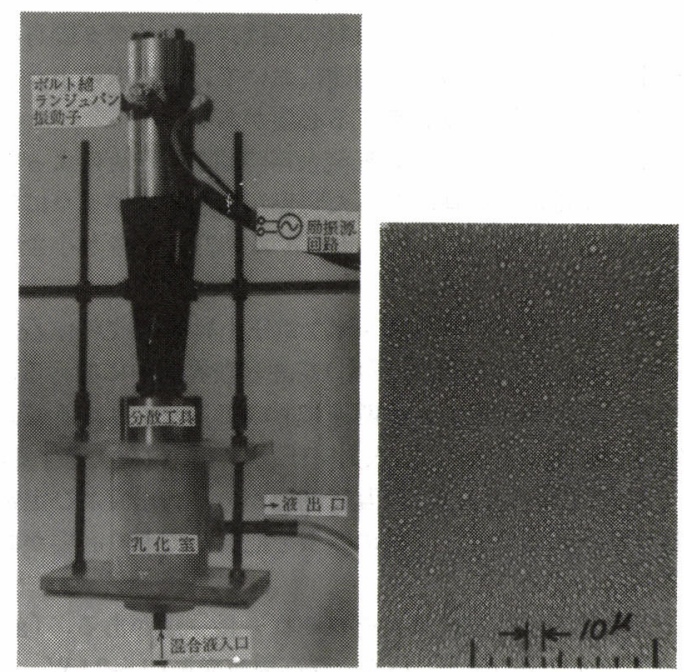

図 1 超音波ホモジナイザと エマルジョン燃料 
いる ${ }^{11}$.

超音波ホモジナイザは，ハイパワ高周波交流を電源と する超音波振動子を駆動し，超音波のキャビテーション 作用により燃料油と水などを乳化・分散する装置 ${ }^{10,12)}$ で ある．すなわち，超音波のキャビテーション作用によっ て分散工具振動面上に発生する真空層の生成消滅の繰返 しにより，燃料油と水が振動面上に接触衝突する現象を 利用して, 油中水滴の乳化，微粒化を実現する．その高 周波電源としては， GTO(ゲートターンオフサイリスタ) 方式あるいはパワートランジスタ方式など種々の方式が 考えられるが, コスト，信頼性及びメンテナンス等の総 合的観点より，現段階では逆導通サイリスタ方式高周波 インバータの実用性が高いと言えよう.

逆導通サイリスタ方式高周波インバータ ${ }^{12)}$ 亿も種々ある が，乙こでは従来の 2 石型高周波インバータの周波数限 界をはるかに越える，新しく開発した中点タップ型高周 波インバータの特性，設計概念等を中心に報告する.

\section{2. 高周波インバータの諸形式}

図 2 (a) 〜 (c) に, 逆導通サイリスタ方式高周波イン バータの諸形式を, 図 $2(\mathrm{~d})$ 亿本文で述べる中点タップ 型高周波インバータを示す. 各スイッチング素子の構成 は，逆導通サイリスタ単独, 高速スイッチングサイリスタ 之高速ダイオードの逆並列接続，あるいはASCR (Asymmetrical Silicon Controlled Rectifiers) 之高速ダ イオードの逆並列構成などが考えられる. 各スイッチン グ素子の構成において，それぞれの基本的スイッチング 動作は等しいが, ターンオフタイム $T_{\text {off }}$ の小さいASCR （RCA 社 S $7310 \mathrm{M}$ で $2.8 \mu \mathrm{s}$ ）が, 周波数限界に関して有 利となる (3.2.1 節 (3)式参照).

逆導通サイリスタを含むいわゆるサイリスタインバー タのハイパワ高周波応用に拉いては, サイリスタ固有の 諸定格と，負荷出力との関連において，特に次のような 点に注意して回路設計をする必要がある.

（i）インバータ回路の転流余裕時間 $T_{\mathrm{c}}$ (転流によって アノード電流がゼロになった時点から逆電圧がゼロにな る時点までの時間)より, サイリスタ $T_{\mathrm{off}}$ 定格が小さい 範囲内で動作させる。

（ii） $\mathrm{d} v / \mathrm{d} t$ (サイリスタオフ電圧上昇率)及び $\mathrm{d} i / \mathrm{d} t$ （サイリスタオン電流上昇率）を許容限界值内に抑える.

（iii）負荷出力電力之の関連において，サイリス夕最大 定格内に納まるように, 入力電圧及び諸定数を決定する.

上記 (i) 〜 (iii) は, 相互に関連があり, 過渡及び定常 特性解析において, 回路の特徴を把握しておく必要があ ろ.

図 2 亿示す各方式は，それぞれ一長一短がある.（a） のブリッジ型の場合, ハイパワ高周波発振 (1〜2kW, 1 $\sim 30 \mathrm{kHz}$ ) が可能だが, 素子数が比較的多い. 入力リプ 儿率 (入力直流に含まれる交流分の割合, 定義は (2)式 参照)ならびに $\mathrm{d} v / \mathrm{d} t$ がかなり大きいなどの欠点があ

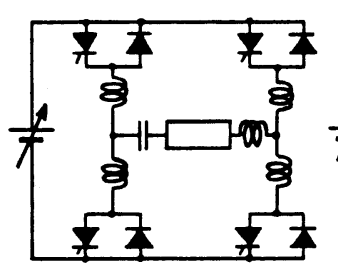

(a)

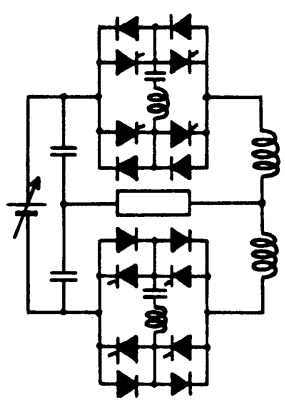

(C)

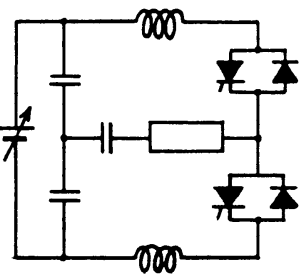

(b)

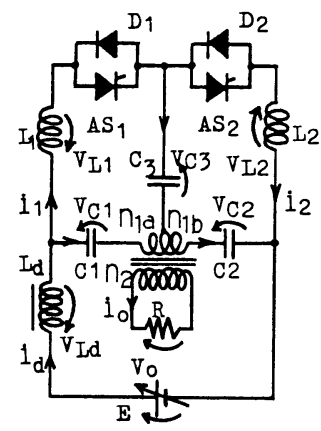

(d)
図 2 逆導通サイリスタ方式高周波インバータの 諸形式 (a) （c) と中点タップ型高周波イ ンバータ (d)

る.（b）のコンデンサ分割型は，素子数が少ないローコ ス卜型と言えるが，その分電力容量も $0.2 \sim 1 \mathrm{~kW}$ と小さ くなる．また，(a)同様に入力のリプル率及び $\mathrm{d} v / \mathrm{d} t$ が かなり大きくなる欠点がある. (c)の時分割方式は，(a) のブリッジ型よりさらにハイパワ高周波発振 (1〜 $3 \mathrm{~kW}$, 1 $50 \mathrm{kHz}$ ) が可能となるが, 素子数がやや多く回路が 複雑となる，制御回路も複雑となり信頼性が低下する， コストが高く $\mathrm{d} v / \mathrm{d} t$ あかなり大きい．以上の従来型逆 導通サイリスタ方式高周波インバータに対して, 今回開 発した (d)の中点タップ型は，素子数が少ないローコス ト型であるにあかかわらず下記のような特長を有す.

（i）中点タップ構成とする事により, 動作周波数 $f_{0}$ が, トリガ周波数 $f_{\mathrm{t}}$ の 2 倍となり，ターンオフタイム $T_{\text {off }}$ との関連における転流余裕時間 $T_{\mathrm{c}}$ が大きい。 した がって, 従来のサイリスタインバータでは実現できなか った $100 \mathrm{kHz}$ 強の高周波発振が可能となった。

(ii) $L_{\mathrm{d}}$ (入力直流リアクトル)インプット構成により, 入力電流リプル率を大幅に軽減できる. しかも，従来の $L_{\mathrm{d}}$ インプット型(電流形インバータ)特有の始動回路が 不要で, 回路構成が簡単である.

（iii）コンデンサ分割型中点タップ方式なので，トラン スの直流偏磁の問題がない.

(jv) $\mathrm{d} i / \mathrm{d} t$ あ小さい.

したがって, 今後 ASCR 単体の電力定格 (容量)の大き いあの, あるいは, 逆導通サイリスタで, $T_{\text {off }}$ の小さいも のが開発されれば，中点タップ型構成でも，大電力高周 波インバータが実現できる.しかし, ハイパワ超音波振動 
子系の応用においては, 現在の振動子単体最大入力が $1.2 \mathrm{~kW}$ なので, 現状の ASCR 定格 (RCA 社 S $7310 \mathrm{~N}$, 順方向阻止最大電圧 $800 \mathrm{~V}$, 順方向電流実効値 $40 \mathrm{~A}, \mathrm{~d} i$ $/ \mathrm{d} t 2000 \mathrm{~A} / \mu \mathrm{s}, \mathrm{d} v / \mathrm{d} t 550 \mathrm{~V} / \mu \mathrm{s}$, ターンオフタイ ム $2.8 \mu \mathrm{s}$ ) に氺いて, 中点タップ型高周波インバータの 実用に際し支障はない.

\section{3. 中点タップ型逆導通サイリスタ方式の 特性評価}

\section{1 回路動作図3 亿中点タップ型逆導通サイ} リスタ方式高周波インバータの，スイッチング素子のオ ン，オフによる各スイッチングモードを示す．始動時過 渡動作に扔いて, ASCR 1 (以降 $A S_{1}$ 之記す)，ASCR 2 (以降 $A S_{2}$ と記す)をトリガする前に, 電源 $E$ が投入され ると，モード(4)により，E， $L_{\mathrm{d}}$ を通して $C_{1} ， C_{2}$ は初 期充電される. 初期充電終了後 $A S_{1}$ がトリガされると, モード(1)に示すように， $C_{1}$ の電荷により $C_{1}-L_{1}-$ $A S_{1}\left(D_{1}\right)-C_{3}$ のループ並びに $E-L_{\mathrm{d}}-L_{1}-A S_{1}\left(D_{1}\right)$ $-C_{3}-C_{2}$ 亿振動電流が流れる. この時, $D_{1}$ の電圧降下 により $A S_{1}$ は逆バイアスされる. 即ち, $D_{1}$ の導通期間 が $A S_{1}$ の転流余裕時間となる. 次に $A S_{2}$ をトリガする 之, 同様にして $C_{2}$ の電荷により $C_{2}-C_{3}-A S_{2}\left(D_{2}\right)-$ $L_{2}$ のループ並びに $E-L_{\mathrm{d}}-C_{1}-C_{3}-A S_{2}\left(D_{2}\right)-L_{2}$ に 振動電流が流れる.とれがモード(3)である。過渡及び 定常時の回路動作に㧧いては, スイッチングモードの切 換る時点における $A S$ あるいは $D$ の電流值により, 次に 起とりうる回路モードが決まる，たとえば，モード(1) に扔いて， $D_{1}$ 電流が導通している時に， $A S_{2}$ をトリガ するとモード(2)の $D_{1} ・ A S_{2}$ 転流重複モードとなる. 次
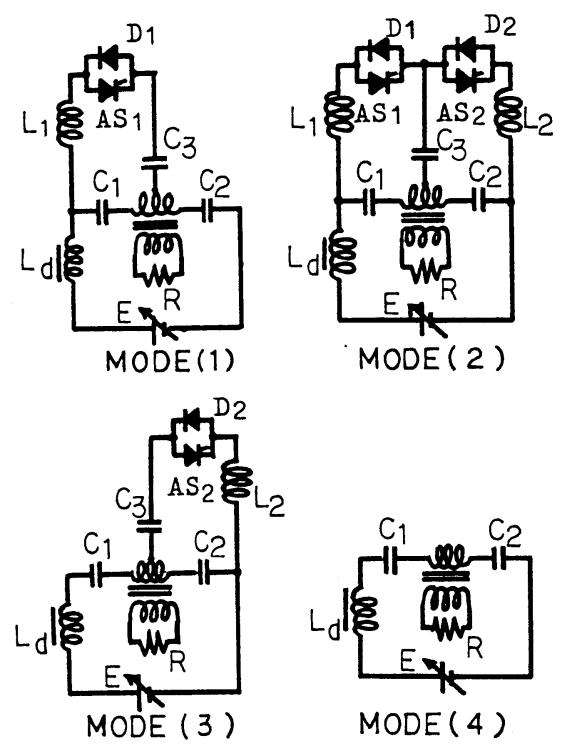

図 3 中点タップ型高周波インバータの スイッチングモード
モードがどのモードになるかは充電初期值，各モード初 期値あるいは各回路パラメータの值により異なる. 各ス イッチング素子のオン, オフ状態により, 次の各モード が考えられる。

$$
\begin{array}{ll}
\text { モード(1) } & A S_{1} \text { 又は } D_{1} \text { 単流モード } \\
\text { モード(2) } & A S_{1} \text { と } D_{2} \text { の転流重複モード } \\
& A S_{2} \text { と } D_{1} \text { の転流重複モード } \\
& A S_{1} \text { と } A S_{2} \text { の転流重複モード } \\
\text { モード(3) } & A S_{2} \text { 又は } D_{2} \text { の単流モード } \\
\text { モード(4) } & A S_{1} ・ A S_{2} \text { 休止モード. }
\end{array}
$$

したがって回路解析に打いては，常に各電流值により次 モードを自動的に判定する必要がある.

\section{2 数值解析回路解析では下記の仮定を設け} る.

（i）ASCR及びダイオードは理想スイッチとする.

(ii) 出力変成器は理想変圧器とする.

（iii）負荷は純抵抗負荷とする.

(iv) 回路状態変数の各電圧, 電流の正の方向を図 2 （d）のとおりとする．また，回路解析及び設計の汎用性 のために, 無次元化パラメータを下記のように定義する.

$$
\mu=2 \pi f_{0} \sqrt{L C}, \lambda=n^{2} R / 2 \sqrt{L / C}
$$

ここで

$$
\begin{aligned}
& L=L_{1}=L_{2}, \quad 1 / C=1 / C_{1}+1 / C_{3}, C_{1}=C_{2} \\
& l=L_{\mathrm{d}} / L, \quad p=C / C_{1}, q=C / C_{3} \\
& f_{\mathrm{t}}: \text { トリガ周波数 } \\
& f_{0}: \text { 動作周波数 }=2 f_{\mathrm{t}} \\
& n: \text { 出力変成器の巻数比 } \\
& 2 \sqrt{L / C}: \text { 無次元化基準インピーダンス } \\
& E: \text { 無次元化基準電压 }=\text { 入力電圧 } \\
& I: \text { 無次元化基準電流 }=E / 2 \sqrt{L / C}
\end{aligned}
$$

したがって， $\mu$ は無次元化動作周波数，またえは無次 元化負荷と考えられる. 各電圧, 電流は, それぞれ $E$ 及 びIによって無次元化され*印を付ける，付録に，無次 元化による各モード状態方程式を示す. 各モード状態方 程式は過渡動作の計算において, 始動初期值として,

$$
\begin{aligned}
& v_{C 1}^{*+0}=v_{C 2}^{*+0}=0.5, \quad v_{C 3}^{*+0}=0 \\
& i_{\mathrm{d}}^{*+0}=i_{1}^{*+0}=i_{2}^{*+0}=0
\end{aligned}
$$

とした. 計算は, 4 次 $R-K$ 数值解析法により, 各モ一 ド初期值の正負により次モードの判定を自動的に行い, 定常状態に至るまで反復計算をした．定常状態の判定は $n$ サイクル目の初期值 $v_{C_{1}(n)}^{*+0}$ と， $(n+1)$ サイクル目の 初期值 $v_{C 1(n+1)}^{*+0}$ の絶対誤差が $0.3 \%$ 以内をあって定常と した.

\section{2 定常諸特性}

3.2.1 $L_{\mathrm{d}}$ の効果 純粋な電流形インバータでは, 入力直流回路の $L_{\mathrm{d}}$ は非常に大きな值で，したがって, 入力電流 $i_{\mathrm{d}}$ はリプルのない直流となる. 一方, 電圧形イ ンバータでは, $L_{\mathrm{d}}$ がないため, 入力直流電流のリプル率 が著しく大きいが，その反面始動回路が必要ない。本方 式インバータでは, との電流形と電圧形の折中形として, 
$L_{\mathrm{d}}$ は比較的小さな值としている.

この $L_{\mathrm{d}}$ の大小は, $\mathrm{d} i / \mathrm{d} t$, 入出力電力, ASCRの電 圧及び電流の最大值 $V_{\mathrm{ASm}}, I_{\mathrm{ASm}}$ さらには周波数限界 $f_{0 \max }$ 等に大きく影響する.こてでは $L_{\mathrm{d}}$ の大小としてリ アクトル比 $l$ を考え，その大小が定常諸特性にどのよう な影響を及ぼすか検討する。なお，図4 から図8 亿示す 特性は， $\mu=0.528, p=0.33$ 及び $n=0.25$ において, $\lambda$ をパラメータとしたものである.

図 4 は, $l=L_{\mathrm{d}} / L$ に対する入力電力平均值 $P_{\mathrm{in}}^{*}$, 入力 直流電流平均值 $I_{\mathrm{d}}^{*}$ を表わしている. 無次元化に打いて は, $P_{\mathrm{in}}^{*}$ と $I_{\mathrm{d}}^{*}$ は等しい. 即ち,

$$
P_{\mathrm{in}}^{*}=P_{\mathrm{in}} / E I=E I_{\mathrm{d}} / E I=I_{\mathrm{d}}^{*}
$$

図 4 において,lの小さい領域においては, 各パラメー タ久において $P_{\mathrm{in}}^{*}, I_{\mathrm{d}}^{*}$ は $l$ の増加に伴い直線的に増加し ている. しかし，l邓50の範囲では， $P_{\mathrm{in}}^{*}, I_{\mathrm{d}}^{*}$ はほぼ飽 和して増加しない事が明らかとなった。

図 5 は, l $l$ 対するASCRのオン電流上昇率 $\mathrm{d} i * / \mathrm{d} z$ を示している. サイリスタでは, ターンオンする時の順 方向電流上昇率 $\mathrm{d} i / \mathrm{d} t$ を, サイリスタの定格值以内に 納める必要がある. ここで, $\mathrm{d} i / \mathrm{d} t$ 定格 $[\mathrm{A} / \mu \mathrm{s}]$ 之, 無 次元化 $\mathrm{d} i * / \mathrm{d} z$ の関係は次式で与えられる.

$$
\begin{aligned}
\mathrm{d} i / \mathrm{d} t[\mathrm{~A} / \mu \mathrm{s}]= & (\mathrm{d} i * / \mathrm{d} z) \times E / 2 \sqrt{L / C} \\
& \times f_{0} \times 10^{-6}
\end{aligned}
$$

したがって, $\mathrm{d} i * / \mathrm{d} z=40$ の場合, $E=200\left[\mathrm{~V}\right.$ ],$f_{0}=$ $10 \times 10^{3}[\mathrm{~Hz}], 2 \sqrt{L / C}=25$ とすると, $\mathrm{d} i / \mathrm{d} t=3.2$ $[\mathrm{A} / \mu \mathrm{s}\rceil$ となる.したがって, 本方式インバータの場合, $\mathrm{d} i / \mathrm{d} t$ に関してはほとんど問題とならない事が明らか となった。

ASCRを用いたインバータでは, 従来のサイリスタ同 様に，最大定格としての ASCR の順方向にかかる最大 電圧 $V_{\mathrm{AS} \mathrm{m}}$ 及び, 順方向最大電流 $I_{\mathrm{ASm}}$ を, 入出力電力之 の関連において考慮しなければならない. 図6は，lに 対するASCR電圧の最大值 $V_{\mathrm{ASm}}^{*}$ を表わしたあのである. 本方式インバータの場合， $V_{\mathrm{ASm}}^{*}$ 亿関しては，lの值をか なり大きく変えてあ各入の值においてそれほど変化しな い事が同図よりわかる. 入力電力 $P_{\text {in }}^{*}$ との関連において は, 入力電力が比較的大きく，しかむ $V_{\mathrm{ASm}}^{*}$ のそれほど大 きくない $l=50, \lambda=0.25$ が設計時パラメータ值として 適当に考えられるが, 他の諸特性, たとえばリプル率 〔\%]あるいは $T_{\text {off }}$ との関連における転流余裕時間 $T_{\mathrm{c}}$ な どの $l$ に対する特性など, 総合的に判断して決定しなけ ればならない。

図 7 は, $l$ に対する入力直流電流 $i_{\mathrm{d}}$ の平均值リプル 率 Rip[\%]を示している. 平均值リプル率 Rip[\%]は下 式で定義される.

ここで,

$$
\operatorname{Rip}[\%]=\left(i_{\mathrm{d} \max }^{*}-i_{\mathrm{d} \min }^{*}\right) / I_{\mathrm{d}}^{*} \times 100
$$

\footnotetext{
$i_{\mathrm{d} \max }^{*}$ :入力直流電流最大值

$i_{\mathrm{d} \min }^{*}$ : 入力直流電流最小値

$I_{\mathrm{d}}^{*}$ : 入力直流電流の平均值
}

Journal of the M.E.S.J., Vol.20, No.5

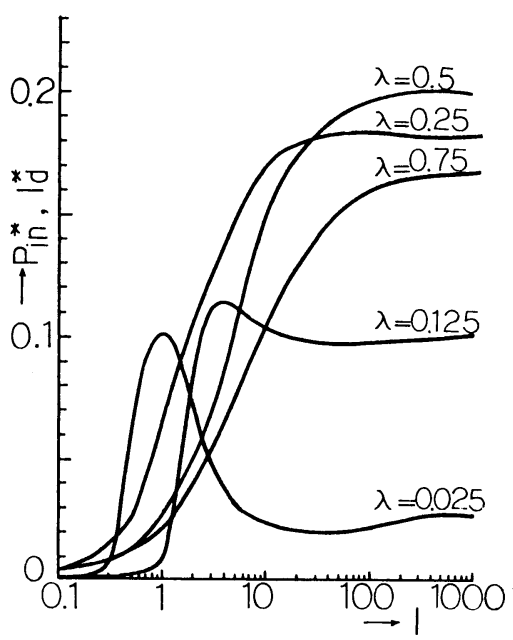

図 $4 \quad l-P_{\mathrm{in}}^{*}, I_{\mathrm{d}}^{*}$ 特性

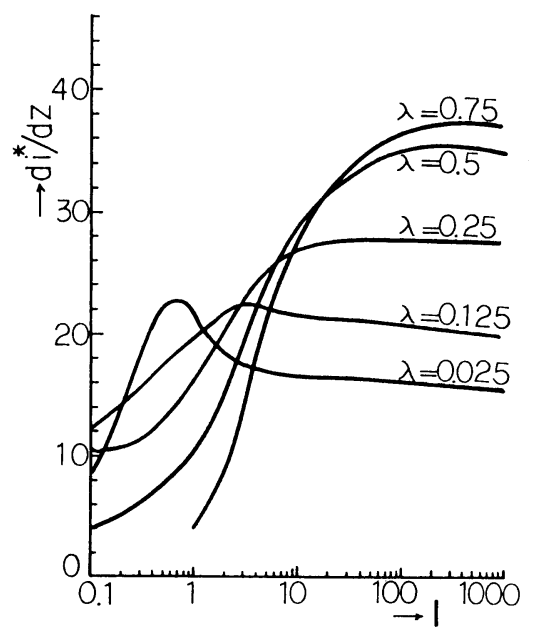

図 $5 \quad l-\mathrm{d} i * / \mathrm{d} z$ 特性

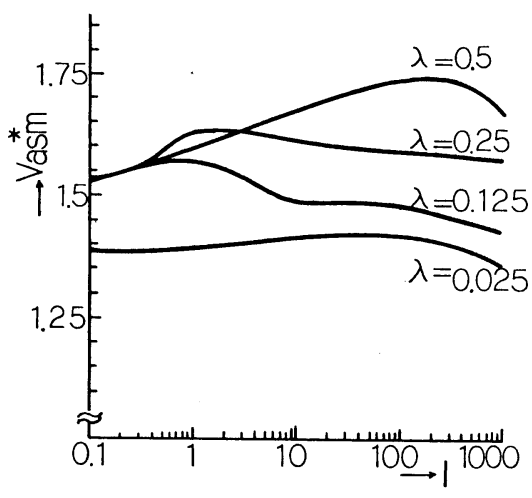

図6 $\quad l-V_{\mathrm{ASm}}^{*}$ 特性 


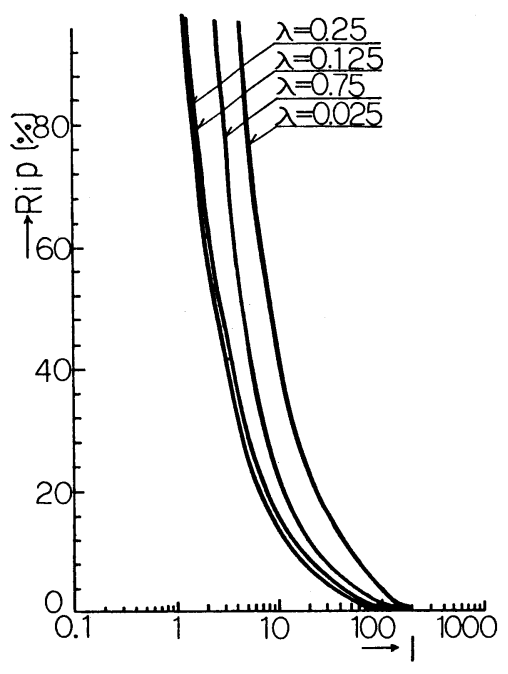

図 $7 \quad l-R i p[\%]$ 特性

図 7 より, lの小さい範囲, 即ち電圧形インバータに おいてはリプル率が異常に大きい. 各入の值において, $l$ の值を 1000 以上にとると, リプル率は激減しゼロに 近づいてくる.乙れがいわゆる電流形インバータで, 電 源は直流電流源とみなされる.したがって，リプル率低 減の観点からは, lを 1000 程度にとる事が望ましいが, $L_{\mathrm{d}}$ の大型化, 重量化につながる. また, 従来の電流形イ ンバータでは， $L_{\mathrm{d}}$ の大形化の原因による始動の困難性 のために，別に始動回路を必要とする. 本方式では, $L_{\mathrm{d}}$ $-C_{1}$-出力変成器 $-C_{2}-E$ の初期充電回路が構成され る事により，特別の始動回路を必要としないのあ大きな 特長の一つとして挙げられる. いずれにせよ，lの值は， 他の諸特性值との関連において, あるいは設計制約条件 との関連において考慮しなければならない.

ASCRを含むサ、リスタ高周波インバータの高周波駆 動においては, $T_{\text {off }}$ との関連における周波数限界 $f_{0 \text { max }}$ が必ず問題となる. 中点タップ型では， $T_{\text {off }}$ を考慮した $f_{0 \max }$ 之, 転流余裕時間の無次元化值 $z_{\mathrm{c}}$ の関係は,

$$
f_{0 \text { max }}=2 z_{\mathrm{c}} / T_{\text {off }}
$$

図 8 にをパラメータとするlに対する $z_{\mathrm{c}}$ を示す. 同 図より， $z_{\mathrm{c}}$ に関しては $l \gtrsim 50$ の範囲においてほぼ一定 の值となる事が判明した.

以上, ASCRを用いた中点タップ型高周波インバータ の安定動作に影響する定常諸特性を総合的に考慮すると, $l$ に関しては, $50 \lesssim l \lesssim 200$ の範囲内を選定するのが適 当と言えよう.

3.2.2 コンデンサ比の影響榋地 $l$ 同様 にコンデンサ比, $p=C / C_{1}, q=C / C_{3}$ の大小は, 定常 諸特性に大きく影響する. こてで， $p$ と $q$ 関係は $p+$ $q=1$ となる. したがって, 以下は $p$ の大小による定常諸 特性の影響について論じる. なお，図 9〜12 は, $\mu=$ 0.528, $l=50, n=0.25$ 一定において，入をパラメータ

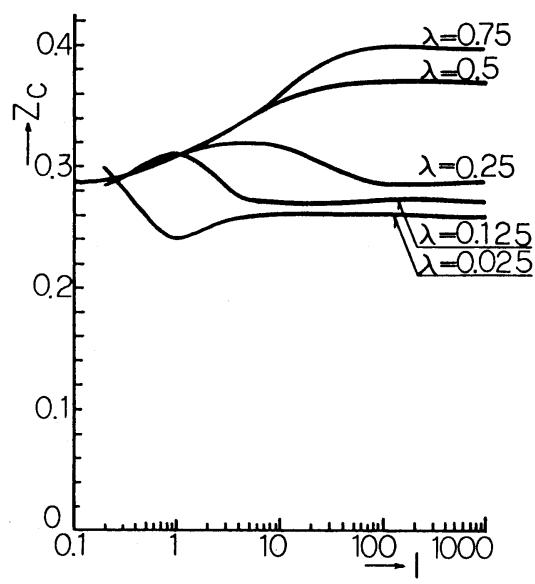

図 $8 \quad l-z_{\mathrm{c}}$ 特性

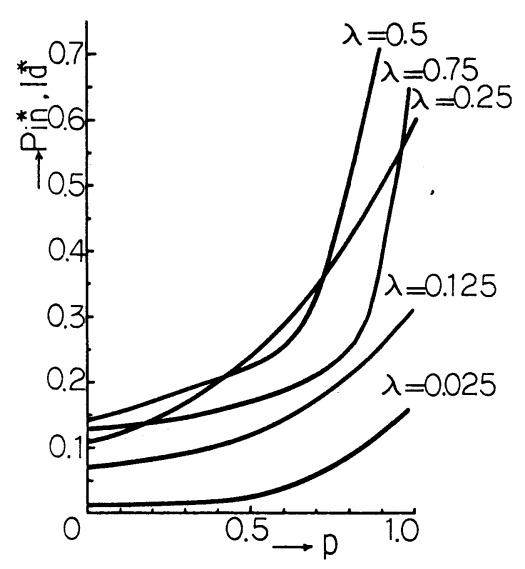

図 $9 p-P_{\text {in }}^{*}, I_{\mathrm{d}}^{*}$ 特性

とした時の諸特性を示す.

図 9 は, $p$ に対する入力電力平均値 $P_{\mathrm{in}}^{*}=$ 入力電流平 均值 $I_{\mathrm{d}}^{*}$ を表わしている. 同図より， $P_{\mathrm{in}}^{*}=I_{\mathrm{d}}^{*}$ に関して は, 各入の值において一様にpの值が大きくなるにつれ 増加の傾向を示している. 従来のコンデンサ分割形高周 波インバータでは, 分割コンデンサ $C_{1}, C_{2}$ の值を $C_{3}$ の 值に対してかなり大きくとり，したがって， $C_{1}, C_{2}$ は電 源分割としてそれぞれ $0.5 E$ であって置き換えられてい た. これを本方式中点タップ型に適用すると, 即ち $p$ を 小さくとると, $P_{\mathrm{in}}^{*}=I_{\mathrm{d}}^{*}$ が大幅に減少し, 装置にパワが 入りにくくなる. パワが入りやすいのは $0.7 \lesssim p \lesssim 1$ 付近 であるが, $l$ 同様, $p-P_{\mathrm{in}}^{*}, I_{\mathrm{d}}^{*}$ 特性のみで $p$ の值を選 定するのではなく，他の諸特性も考慮しなければならな い.

図 10 は $p$ に対するオン電流上昇率 $\mathrm{d} i * / \mathrm{d} z$ を表わして いる. 同図より $p-P_{\mathrm{in}}^{*}, I_{\mathrm{d}}^{*}$ 特性同様に, $\mathrm{d} i * / \mathrm{d} z$ は $p$ の増加につれ一様に上昇する事が明らかとなった. 特に $\lambda=0.5,0.75$ の場合, $p=0.9$ 付近で急激に上昇する傾 


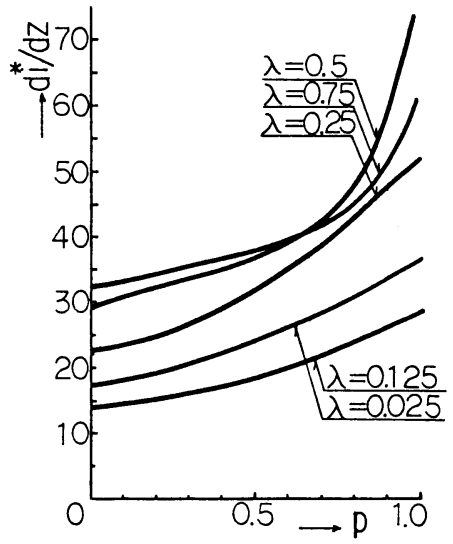

図 $10 p-\mathrm{d} i^{*} / \mathrm{d} z$ 特性

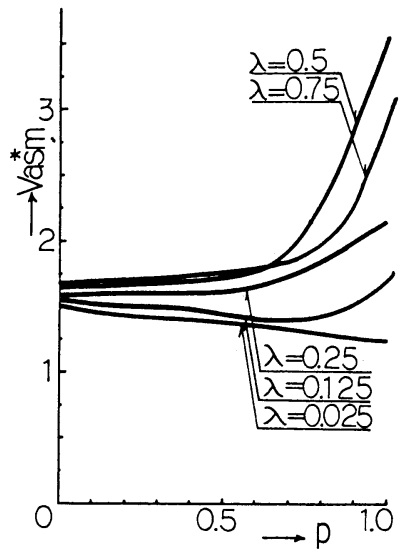

図 $11 p-V_{\mathrm{ASm}}^{*}$ 特性

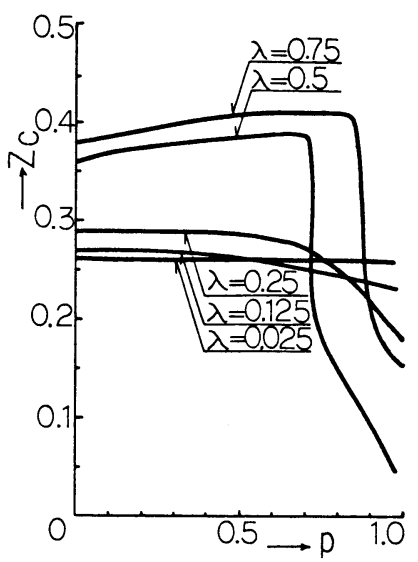

図 $12 p-z_{\mathrm{c}}$ 特性
向があり，注意を要す.しかし，市販の ASCR $\mathrm{d} i / \mathrm{d} t$ 定格 $2000 \mathrm{~A} / \mu \mathrm{s}$ と比較して，ほぼpの全領域において 本方式インバータの場合は $\mathrm{d} i / \mathrm{d} t$ に関しては問題には ならないと考えられる.

図 11 は，pに対するASCR にかかる順方向電压最大 值 $V_{\mathrm{ASm}}^{*}$ を表わしている. 無次元化值 $V_{\mathrm{ASm}}^{*}$ と，実際の $V_{\mathrm{ASm}}\left[\mathrm{V} 〕\right.$ 関係は, $V_{\mathrm{ASm}}=E \cdot V_{\mathrm{ASm}}^{*} \cdot V_{\mathrm{ASm}}^{*}$ に関しては, $p \lesssim 0.7$ 領域では大きな変化はないが, やはり, $p \gtrsim 0.8$ 領域で急増する.たとえば, $\lambda=0.5, p=0.9$ で $V_{\mathrm{ASm}}^{*}$ ： 3.0 となる.したがって, $E=200[\mathrm{~V}]$ とすると, $V_{\mathrm{ASm}} \doteqdot$ $600[\mathrm{~V}]$ となるで，最大定格の観点から注意を要す。

図 12 は， $p$ に対する転流余裕時間 $z_{\mathrm{c}}$ を示している. 各入の值に拉いて, $p \lesssim 0.7$ では $p$ の増減に対する $z_{\mathrm{c}}$ の 影響は小さい. しかし, $p>0.7$ 領域, 特に $\lambda=0.5,0.75$ の場合, $p$ の微少変化により $z_{\mathrm{c}}$ が跳躍する領域が明ら かよなった， $z_{\mathrm{c}}$ の跳躍現象は後節で詳述するが，てのよ うな領域の回路設計は避けるべきと言えよう。

以上の $p$ に対する定常諸特性を総合的に考慮すると， $p$ に関しては $P_{\mathrm{in}}^{*}=I_{\mathrm{d}}^{*}$ が比較的大きく, $V_{\mathrm{ASm}}^{*}$ は逆に小さ く最大定格の面で余裕度があり, しかあ $z_{\mathrm{c}}$ の変動の少 ない領域として， $0.3 ミ p \leqq 0.7$ の值が適していると考え られる。

3.2 .3 負荷特性 回路設計においては負荷変動に 対する諸特性の変化を把握しておく事が必要となる．本 文に沶いて無次元化負荷は入となる．超音波ホモジナイ ザの設計において, 定格出力, 共振周波数及び駆動負荷 条件において入の選定を実施する.また，実際の駆動に おいて, 駆動負荷条件が変化するとスも変化する．たと えば重油の粘度，水分\%，流量，液深さらには乳化室に おける分散工具底面におけるクリアランスなよ゙。したが って，入に対する諸特性を把握した上で入の最適值を選 定しなければならない。

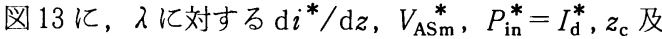
びRip[\%]を表わす. 但し $, \mu=0.528, l=50, p=0.67$ 及び $n=0.25$. 同図において, $\lambda$ の増加につれ $\mathrm{d} i * / \mathrm{d} z$,

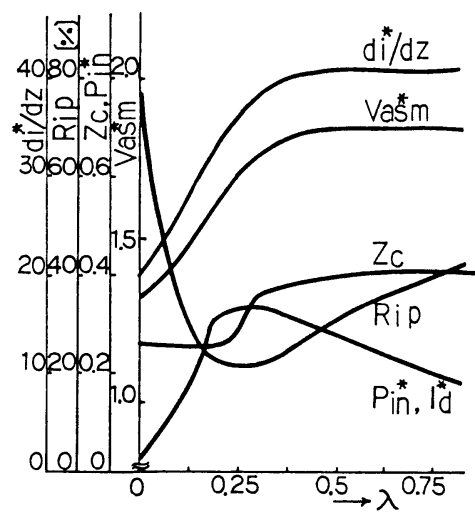

図 13 負荷諸特性 
$z_{\mathrm{c}}$ 及び $V_{\mathrm{ASm}}^{*}$ は一様に増加の傾向を示すが, $\lambda \gtrsim 0.375$ 領

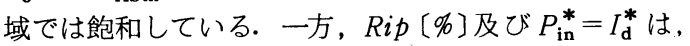
$\lambda=0.25$ 付近でそれぞれ最小及び最大となっている. 回 路設計の観点からは， $P_{\mathrm{in}}^{*}=I_{\mathrm{d}}^{*}$ が大きい, 即ちパワが入 りやすく，周波数限界における余裕度の点において $z_{\mathrm{c}}$ が大きく，しかも安定動作上 $\mathrm{d} i * / \mathrm{d} z, V_{\mathrm{ASm}}^{*}$ 及びRip 〔\%]が小さい事が望ましい. しかし，一般に $P_{\text {in }}^{*}$ が大き くなれば，当然 $V_{\mathrm{ASm}}^{*} や \mathrm{~d} i * / \mathrm{d} z$ が大きくなるので, 回路 設計においてはハイパワ超音波振動子系の定格出力, 動 作周波数及び使用する市販のスイッチング素子の定格の 中で, 何が一番の制約条件になるのかを見極めて入を選 定する必要がある.

計測用超音波振動子に対し, 動力用のハイパワ超音波 振動子の動作周波数帯は, $20 \mathrm{kHz}, 25 \mathrm{kHz}$ 及び $30 \mathrm{kHz}$ 前後と，いわゆる高周波の中でも低い方であり，しかも 本方式中点タップ型では $T_{\text {off }}$ を考慮した実質的周波数限 界は $100 \mathrm{kHz}$ と転流余裕度は大きい. したがって, 以上 の点を総合的に考慮すると, 回路設計においては $\lambda=0.3$ 付近を選定するのが適当と言えよう.

\section{3 過渡特性と $z_{\mathrm{c}}$ の跳躍現象 本方式インバ} 一タを含む逆導通サイリスタ方式高周波インバータでは, 始動加ら定常状態に至る数百 $\mu \mathrm{s}$ の過渡動作において, 各特性值 $\left(V_{\mathrm{ASm}}^{*}, I_{\mathrm{ASm}}^{*}, \mathrm{~d} i^{*} / \mathrm{d} z, z_{\mathrm{c}}\right.$ など) が, 各サイク ルごとに増減する. 中であ $z_{\mathrm{c}}$ が著しい変化を示す. 始 動時過渡動作においても, 動作周波数限界は, (3)式で 決まるので, したがって実質的には過渡動作における $z_{\mathrm{c}}$ の最小值によって $f_{0 \max }$ が限定される.

図 14 に, 始動時過渡動作における $z_{\mathrm{c}}$ の過渡応答を示 す.なお，図 14 は, $\mu=0.528, l=50, p=0.67, n=0.25$ 一定とし，入をパラメータとする各サイクルごとの $z_{\mathrm{c}}$ の 変動を示すあのである. 同図より， $\lambda=0.75$ 及び $\lambda=0.5$ の場合, 過渡動作に拈いて $z_{\mathrm{c}}$ の著しい跳躍現象が明ら かとなった， $z_{\mathrm{c}}$ の跳躍現象は，図 3 に示すスイッチング モードの転移によるもので, $z_{\mathbf{c}}$ の跳躍の結果, 過渡動作 における $z_{\mathrm{c}}$ 最小值と定常值の開きが大きくなる.たと えば， $\lambda=0.5$ の場合, 過渡動作 $z_{\mathrm{c}}$ 最小值は, $n=3.5$ サ イクル目の $z_{\mathrm{c}}=0.1$ であるが, 定常状態における $z_{\mathrm{c}}$ の值

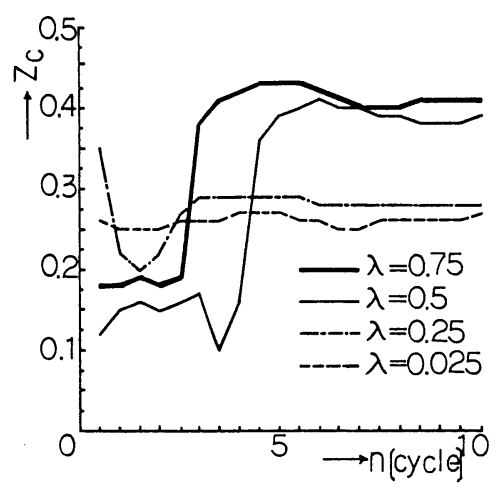

図 $14 z_{\mathrm{c}}$ 過渡応答
は 0.38 となっている.したがって, 実質的周波数限界は, $z_{\mathrm{c}}=0.1$ によって制約される.

このような $z_{\mathrm{c}}$ の跳躍現象は, 過渡動作のみでなく 3.2 .2 図 12 で述べたように，定常特性における $p$ あるいは $l$ の変化においてあ起とりうる. これは逆導通サイリスタ 方式高周波インバータのスイッチングモード転移におけ る特有の現象であるが, $z_{\mathrm{c}}$ の跳躍時点で, 他の諸特性

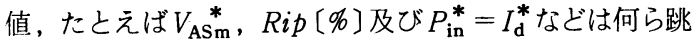
躍しない. したがって, この跳躍現象は， $z_{\mathrm{c}}$ と $T_{\text {off }}$, $f_{0 \max }$ との関連においてのみ考慮しなければなら問題 である・

図 15 に $\lambda=0.75, \mu=0.528, p=0.66, l=50$ 及び $n=0.25$ における始動から定常に至る過渡動作波形の一 部を示す. この型のインバータにおける $z_{\mathrm{c}}$ は, ダイオー ドの導通期間として数値計算より求められる. 図 15 に おいて $z=2.5$ において $A S_{2}$ の電流 $i_{2}$ はまだゼロクロス していない. 即ち $D_{2}$ は導通していない. ての時点で $A S_{1}$ がトリガされると， $A S_{1}$ と $A S_{2}$ の転流重複モードとな る. そのモード期間中に $A S_{2}$ はゼロクロスして, $D_{2}$ と $A S_{1}$ の転流重複モードとして $z_{\mathrm{c}}=0.19$ の期間 $D_{2}$ が導通 する. 一方, $z=3.0$ において $A S_{2}$ をトリガした時は, 既に $D_{1}$ は， $z=2.83$ において導通しており， $z_{\mathrm{c}}=0.38$ の 期間導通する. この時点で, $z_{\mathrm{c}}=0.19$ から $z_{\mathrm{c}}=0.38$ の跳 躍現象が発生している. このような跳躍現象は, 各パラ メータを変えた数值計算の結果, 次のように説明される. ASCRを流れている電流 $i_{1}$ 又は $i_{2}$ が, トリガリングの 半周期の間にゼロクロスしないと， $A S_{1}, A S_{2}$ 重複モー ドとなり，その後に $A S$ とDの転流モードとなる．との 場合のダイオードの導通期間, 即ち転流余裕時間 $z_{\mathrm{c}}$ は小 さい. ところが, トリガリングの半周期の間にゼロクロ スし， $A S$ とDの転流重複モードが存在すると，その場 合のダイオード導通期間は長く， $z_{\mathrm{c}}$ は大きくなる. 一方, ASCRの電流がゼロクロスして, ダイオードが導通して 屯, 半周期中にダイオード電流が再びゼロクロスすると

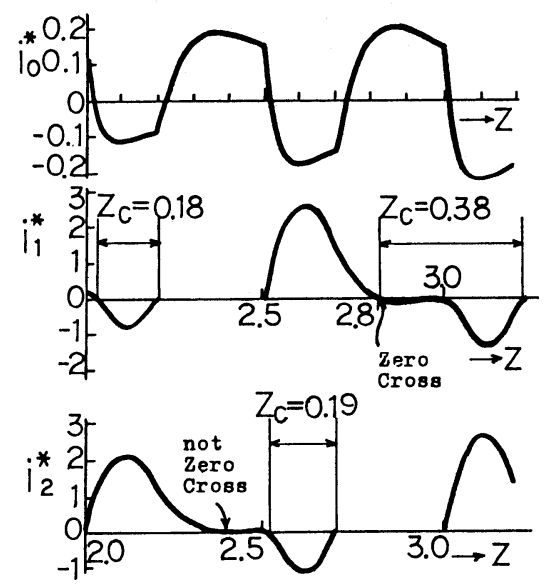

図 15 過渡動作における $z_{\mathrm{c}}$ 跳躍 
この場合の $z_{\mathrm{c}}$ あ小さくなる.すなわち，

$A S_{1}, A S_{2}$ 休止モード $\rightarrow D_{2} \cdot A S_{1}$ 又は $D_{1} \cdot A S_{2}$ 重複 モード $\rightarrow A S_{1} \cdot A S_{2}$ 転流重複モード

の, 上記スイッチングモード転移時点において， $z_{\mathrm{c}}$ の跳 躍現象が発生する事が明らかとなった。

\section{4. 実 験 結果}

図 16 亿, 過渡及び定常動作における出力電圧の計算 及び実験波形を示す. 理論值と実験值との間に若干の詔 差があるが、解析における仮定を考慮するとその誤差も 小さく，傾向はよく一致している.

な扔，本方式中点タップ型高周波インバータの解析に おいては, 高周波インバータのハイパワ超音波励振源以 外の応用む意図して, 純抵抗負荷で解析した。

エマルジョン燃料等を生成するハイパワ超音波振動子 としての電歪形振動子の負荷等価回路は $R-C$ 負荷等価

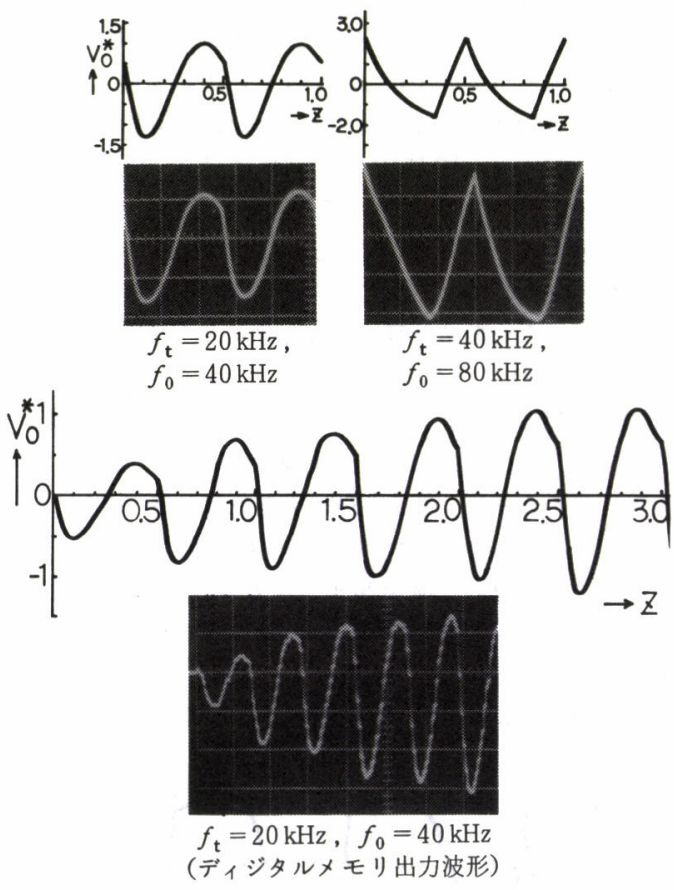

図 16 過渡 (下) 及び定常 (上) 出力電圧波形 $\lambda=0.25, l=50, p=0.33, n=0.25$
回路となる. 今, この $C$ 亿直列に $L$ を接続し， $L-C$ 共 振回路を構成すると、インバータ側から見た負荷は，純 抵抗負荷として表わされる.

\section{5.あとがき}

本文では, ハイパワ超音波励振源の一方式として, 100 $\mathrm{kHz}$ の高周波発振が可能な ASCRを用いた中点タップ 型高周波インバータの過渡及び定常諸特性について, 回 路設計の技術的な観点より論じた.

今後の課題として, $\mathrm{d} v / \mathrm{d} t$ 対策としてのスナバ回路 の解析法と設計の問題がある. 即ち, 高周波インバータ では, サイリスタがオフする時の電圧上昇率 $\mathrm{d} v / \mathrm{d} t$ が かなり大きくなる，したがって，それを抑制するために サイリスタに並列に $R-C$ スナバ回路を実用に扔いては 接続する.この $R-C$ スナバ回路を含めた回路解析は, 相当複雑なために，てれまでに試行錯誤的にその定数を 決めているのが現状であるが，その解析法と設計につい ては現在検討中であり，別の機会に報告したい。

なお，最後に，本研究に関連して，エマルジョン燃料 の有用性之問題点についてで討論戴いた, 東京商船大学 岡田博助教授に謝意を表する次第です。

\section{文献}

1）石渡 · ほ 2 名, 電子通信学会研究会資料US 80-26, (昭 55-8), 49 56

2）日聖・ほ加 4 名, 舶機誌, 18-3 (昭 58-3)

3) E. Cottel, Trans. Ultrasonics (1975-3), 51

4）畑中 · 大西, 舶機誌, 18-4 (昭 58-4)

5) Hall, R. E., Trans. ASME, Journal of Engineering for Power (1976), 425

6) Thompson, R. V., et al, Trans. I. Mar. E (C), Vol. 93, Paper C81 (1981), 19 25

7）三橋・ほ加 5 名，三菱重工技報，Vol, 15, No. 2, (昭 53-3)

8) P. P. Singh, et al, Trans. ASME, Journal of Engineering for Power (1983), 430

9) Ole Groene •ほか 2 名, 舶機誌, 17-9 (昭 57-9), 748

10）西川栄一, 舶機誌, 17-9 (昭 57-9), 714

11）渡辺哲哉, 「化学装置」, (1961-8)

12) Y. Hatanaka, IEEE Intelec 83, (1983-10), 226 


\section{〔付録〕各モード状態方程式}

\begin{tabular}{|c|c|c|c|c|c|c|c|c|c|c|}
\hline \multicolumn{11}{|c|}{$E-ト ゙(1)$} \\
\hline \multirow{5}{*}{$\frac{\mathrm{d}}{\mathrm{d} z}$} & $v_{C_{1}}^{*}$ & \multirow{5}{*}{$=\frac{4 \pi}{\mu}$} & 0 & 0 & 0 & $p / 4$ & $-p / 4$ & $v_{C_{1}}^{*}$ & \multirow{5}{*}{$+\frac{4 \pi}{l \mu}$} & 0 \\
\hline & $v_{C 2}^{*}$ & & 0 & 0 & 0 & $p / 4$ & 0 & $v_{C 2}^{*}$ & & 0 \\
\hline & $v_{C 3}^{*}$ & & 0 & 0 & 0 & 0 & $q / 4$ & $v_{C 3}^{*}$ & & 0 \\
\hline & $i_{\mathrm{d}}^{*}$ & & $-1 / l$ & $-1 / l$ & 0 & $-4 \lambda / l$ & $-2 \lambda / l$ & $i_{\mathrm{d}}^{*}$ & & 1 \\
\hline & $i_{1}^{*}$ & & 1 & 0 & -1 & $2 \lambda$ & $-\lambda$ & $i_{1}^{*}$ & & 0 \\
\hline
\end{tabular}

モード(2)

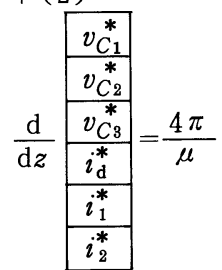

\begin{tabular}{|c|c|r|c|c|c|}
\hline 0 & 0 & 0 & $p / 4$ & $-p / 4$ & 0 \\
\hline 0 & 0 & 0 & $p / 4$ & 0 & $-p / 4$ \\
\hline 0 & 0 & 0 & 0 & $q / 4$ & $-q / 4$ \\
\hline$-1 / l$ & $-1 / l$ & 0 & $-4 \lambda / l$ & $2 \lambda / l$ & $2 \lambda / l$ \\
\hline 1 & 0 & -1 & $2 \lambda$ & $-\lambda$ & $-\lambda$ \\
\hline 0 & 1 & 1 & $2 \lambda$ & $-\lambda$ & $-\lambda$ \\
\hline
\end{tabular}

\begin{tabular}{|l|l|}
\hline$v_{C_{1}}^{*}$ \\
\hline$v_{C_{2}}^{*}$ \\
\hline$v_{C 3}^{*}$ \\
\hline$i_{\mathrm{d}}^{*}$ \\
\hline$i_{1}^{*}$ \\
\hline$i_{2}^{*}$ \\
\hline
\end{tabular}

モード(3)

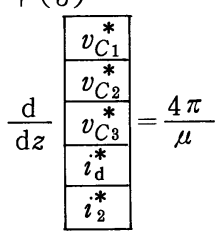

\begin{tabular}{|c|c|c|c|c|}
\hline 0 & 0 & 0 & $p / 4$ & 0 \\
\hline 0 & 0 & 0 & $p / 4$ & $-p / 4$ \\
\hline 0 & 0 & 0 & 0 & $-q / 4$ \\
\hline$-1 / l$ & $-1 / l$ & 0 & $-4 \lambda / l$ & $-2 \lambda / l$ \\
\hline 0 & 1 & 1 & $2 \lambda$ & $-\lambda$ \\
\hline
\end{tabular}

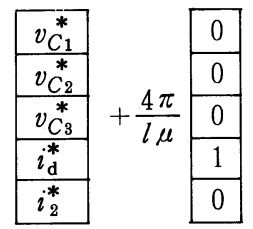

モード(4)

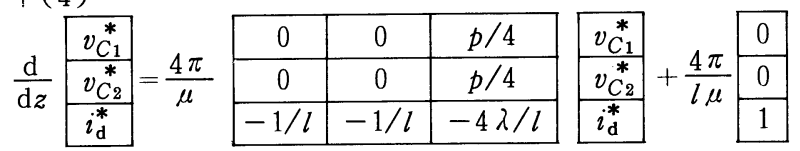

各モード共通に, 出力電流 $i_{0}^{*}$, 出力電圧 $v_{0}^{*}$ は,

$$
\begin{aligned}
& i_{0}^{*}=n\left(2 i_{\mathrm{d}}^{*}-i_{1}^{*}-i_{2}^{*}\right) \\
& v_{0}^{*}=\lambda i_{0}^{*} / n^{2}
\end{aligned}
$$

$\mathrm{ASCR}$ の電圧 $v_{\mathrm{AS} 1}^{*}, v_{\mathrm{AS} 2}^{*}$ は,

$$
\begin{array}{ll}
\text { モード(1), } & \text { モード(4)で, } v_{\mathrm{AS} 2}^{*}=n v_{0}^{*}+v_{C 2}^{*}+v_{C 3}^{*} \\
\text { モード(3), } & \text { モード(4)で, } \\
v_{\mathrm{AS} 1}^{*}=n v_{0}^{*}+v_{C 1}^{*}-v_{C 3}^{*}
\end{array}
$$

となる。 